\title{
1 Evaluation of floristic diversity in urban areas as a basis
}

\section{for habitat management}

3 Muratet, Audrey ${ }^{1 *}$; Porcher, E. ${ }^{1,2,3}$; Devictor, V. ${ }^{2,4}$; Arnal G. ${ }^{1,5}$; Moret, J. ${ }^{1,6}$; Wright, S. ${ }^{7,8}$;

4

6

$$
\text { Machon, } \mathrm{N}^{\cdot 1,2,9}
$$

${ }^{1}$ Conservatoire botanique national du Bassin parisien, UMS Inventaire et suivi de la Biodiversité, Muséum national d'Histoire naturelle, 61 rue Buffon F-75005 Paris, France; ${ }^{2}$ UMR 5173, Conservation des Espèces, Restauration et suivi des Populations, Muséum national d'Histoire naturelle, 61 rue Buffon F-75005 Paris, France; ${ }^{3}$ Email porcher@mnhn.fr; ${ }^{4}$ Email devictor@mnhn.fr; ${ }^{5}$ Email arnal@mnhn.fr; ${ }^{6}$ Email moret@mnhn.fr; ${ }^{7}$ Department of Botany, University of Wisconsin, 430 Lincoln Drive, Madison, WI 53706, USA;

${ }^{8}$ Email sdwright2@wisc.edu; 9 Email machon@mnhn.fr;* Corresponding author ; Fax +33 1407935 53;

Email muratet@mnhn.fr 


\section{ABSTRACT}

2 Questions: How can floristic diversity be evaluated in conservation plans, to identify sites of

3 highest interest for biodiversity? What are the mechanisms influencing the distribution of

4 species in human-dominated environments? What are the best criteria to identify sites where

5 active urban management is most likely to enhance floristic diversity?

6 Location: The Hauts-de-Seine district bordering Paris (France).

7 Methods: We described the floristic diversity in one of the most urbanized French districts

8 through the inventory of ca. 1000 sites located in 23 habitats. We built a new Index of

9 Floristic Interest (IFI), integrating information on richness, indigeneity, typicality and rarity of species, to identify sites and habitats of highest interest for conservation. Finally, we explored the relationship between site IFI and Land Use Patterns

12 Results: We observed a total of 626 vascular plant species. Habitats with highest IFI were typically situated in "semi-natural" environments or environments with moderate human impacts. We also showed that neighboring (urban) structures had a significant influence on the floristic interest of sites: for example, the presence of collective dwellings around a site had a strong negative impact on IFI.

Conclusions: Our approach can be used to optimize management in urban zones; we illustrate such possibilities by defining a 'Site Potential Value', which was then compared with the observed IFI, to identify areas (e.g. river banks) where a better management could improve the district's biodiversity.

22 Key-words: Index of Floristic Interest, Land Use Pattern, Spatial distribution, Urban biodiversity, Habitat units, Human impact, Conservation, Environmental planning 


\section{INTRODUCTION}

2 Biodiversity in urban areas has long been neglected by ecologists, because urban ecosystems

3 were regarded as highly disturbed and supporting relatively common species. Although the

4 latter assertion is generally true (Kühn \& Klotz 2006), considering urban biodiversity and the

5 mechanisms that control its dynamics is of major importance for conservation biology. First,

6 urbanization is a central component of land-transformation processes worldwide and one of

7 the leading causes of species extinction (McKinney 2006). Cities are often located at the crossroads of major communication routes and may act as 'hotspots' of invasive species, which generally thrive in disturbed habitats. Understanding the mechanisms underlying the dynamics of invasive species, and biodiversity in general, in urban habitats is thus central to slow down the loss of biodiversity inside and outside cities. In addition, a majority of the world's human population lives in urban areas (Grimm et al. 2000), where the existence of healthy green zones supporting a variety of plant and animal species has been shown to contribute to human welfare (Tzoulas et al. 2007).

As a result of conservation and human welfare concerns, extensive studies of biodiversity, especially flora, have started to emerge in urban areas. A number of these studies were specific to a single habitat or land-use type, such as woodlands (Goodfellow \& Peterken 1981; Godefroid \& Koedam 2003), wetlands (Mushet et al. 2002), wastelands (Muratet et al. 2007) or parks and gardens (Hermy \& Cornelis 2000; DeCandido 2004; Thompson et al. 2004). However, a growing number of studies also addressed the distribution of common flora across all urban zones (see Pysek 1998 for a review) using standardized sampling (e.g. Berlin, Germany, Zerbe et al. 2003; Brussels, Belgium, Godefroid 2001; Plymouth, England, Kent et al. 1999; Birmingham, England, Angold et al. 2006; Rome, Italy, Ricotta et al. 2001; and Almeria, Spain, Dana et al. 2002). These studies showed that cities harbor relatively high plant diversity due to the co-existence of a large variety of habitats. However, urbanization is 
1 also generally associated with increased frequency of alien species and loss of some habitat2 specialist plants, such as wetland species.

3 Although these large-scale inventories of urban floristic diversity carry key information to 4 understand the dynamics of biodiversity in urban areas, they remain mostly descriptive, i.e. 5 they do not investigate the mechanisms responsible for observed patterns. The first studies in 6 mechanistic urban ecology are recent (reviewed in Shochat et al. 2006) and concern animal 7 populations mainly. Studies examining the floristic composition in the different land use types and assessing the impact of urban structures on floristic diversity are scarce (Kent et al. 1999; Roy et al. 1999; Maurer et al. 2000; Zerbe et al. 2003; Godefroid \& Koedam 2007). Such knowledge is however necessary to incorporate biodiversity in urban planning and favour the maintenance of diverse urban ecosystems (Lofvenhaft et al. 2002). In the present study, we examine plant diversity in one of the most urbanized French districts (Hauts-de-Seine) and explore the potential influence of urbanization and urban structures on such diversity. We undertook a comprehensive habitat mapping (as in Sukopp \& Weiler 1988) and performed about 1000 inventories to evaluate the floristic interest of sites and habitats. Our aims were:

(1) To describe species distribution over the whole region and locate areas of highest interest for plant diversity. Following previous studies describing site quality (Ratcliffe 1977; Wittig \& Schreiber 1983; Swink \& Whilelm 1994; Maleyx 2001; Godefroid et al. 2003 and reviewed in Spellerberg 1992), we defined a new Index of Floristic Interest (IFI), combining information on richness, indigeneity, typicality and rarity of species present in a site or habitat. The use of IFI allowed us to rank habitats according to their contribution to the district's biodiversity.

(2) To evaluate the influence of urbanization on the floristic diversity of sites. Using data from the Land Use Pattern, we explored the relationship between site floristic interest and the presence of various urban structures around sites. 
1 (3) To identify habitats and sites where active urban management is most likely to enhance 2 floristic diversity. Using the available knowledge on the influence of urban structures on 3 floristic interest, we built an index of Site Potential Value (SPV) that can be used to direct 4 urban planning. 


\section{Study area}

3 The Hauts-de-Seine district (French administrative 'département') is a crescent-shaped area of

$4176 \mathrm{~km}^{2}$ (Fig.1) bordering the west of Paris (4850’ N; $2^{\circ} 14^{\prime}$ E). The climate is oceanic with

5 continental trends (mean annual temperature: $11.7^{\circ} \mathrm{C}$ and annual rainfall: $641 \mathrm{~mm}$ ). Hauts-de-

6 Seine is composed of (1) a plain, (2) small hills, which reach $180 \mathrm{~m}$ at their highest point and

7 are least favorable to urbanization and (3) a plateau, divided into 5 sub-regions by small

8 valleys, relics of ancient waterways. The Seine River borders the northern part of the district

9 for $39 \mathrm{~km}$. This district is one of the most densely populated areas of France (8118 vs. 95

10 people $/ \mathrm{km}^{2}$ on average in France, INSEE 1999). Built zones have covered about $70 \%$ of the

11 territory for over 20 years (IAURIF 2003).

12

13

14

\section{Sampling design and inventories}

Using an exhaustive map of green spaces in Hauts-de-Seine (“cadastre vert”, Dewilde \& Lafréchoux 2001), we calculated the total area occupied by each of 10 types of green spaces in the district. Inventory sites were sampled at random within each type; the area inventoried in each green space type was proportional to its total area in the district (proportional stratified sampling). Inventory sites were generally defined as the total area covered by a given plant community (used as a proxy for habitat type), and thus ranged from 3.39 to 116 $415 \mathrm{~m}^{2}$, except in forests where sites were forester-defined stands (from 806 to $40842 \mathrm{~m}^{2}$ ). Following Westhoff \& Werner (1983) and Kendle \& Forbes (1997), each habitat type was assigned to one of three levels of anthropogenic impact: "semi-natural”, "intermediate" or “anthropogenic” (Table 1).

Between 2001 and 2005, we inventoried a total of 986 sites, in which we recorded all present wild vascular species once, in spring, summer or autumn. Species were classified as 
1 "indigenous" or "naturalized" according to a list compiled by professional botanists of the

2 National Botanical Conservatory of the Parisian region (CBNBP 2008). Naturalized species

3 are non-indigenous species that now behave like indigenous species (Richardson et al. 2000).

4 We dismissed cultivated or casual species that may reproduce occasionally in an area, but

5 which do not form self-replacing populations and are unlikely to contribute significantly to

6 community processes.

\section{Quantifying floristic interest: Index of floristic interest}

8 Species richness (Rich), the total number of species observed in a given location, is a widely

9 used measure of biodiversity to evaluate habitat or site interest for conservation. However, not all species are equivalent and some of their characteristics should be incorporated to describe site interest accurately. Rare species, for example, often receive special attention in conservation programs. We measured the rarity of a species as the proportion of district sites in which it was not observed. Species rarity varied between 0.999 (e.g. for Callitriche stagnalis Scop. and Serratula tinctoria L., inventoried only once in 986 sites) and 0.365 (e.g. for Taraxacum campylodes G.E.Haglund inventoried in 626 sites). A site rarity index (Rar) was calculated as the average rarity over all species. We also considered two other characteristics that potentially influence conservation choices: indigeneity (Ind), the proportion of indigenous species (see definition above) and typicality (Typic), the proportion of typical species in each site. Typical species are habitat-specific species that were observed in a single habitat type in the Hauts-de-Seine (e.g. Myriophyllum spicatum L. was observed in aquatic habitats only -nine sites- and Calluna vulgaris (L.) Hull in Oak groves only -eight sites).

These four indices were significantly but weakly correlated across sites (Spearman rank correlation coefficient between 0.04 and 0.39 ), so that the information they carry is largely complementary. Using a one way ANOVA, we showed that there were strong differences 
1 among seasons of inventory for all indices $(\mathrm{P}<0.005)$; to correct for the season effect, the four

2 indices were thus incorporated as follows to build the "Index of Floristic Interest” (IFI):

$$
\text { IFI = 1/4(Rich/Richmax }+ \text { Typic/Typicmax }+ \text { Ind /Indmax }+ \text { Rar/Rarmax })
$$

where each index is standardized by its maximum value observed in a given season, which

removes differences in IFI among seasons. By construction, IFI lies between 0 and 1 (highest

6 floristic interest) and can be defined at the site or habitat (mean across sites) level.

\section{Impact of urbanization on floristic interest}

\section{Characteristics of urbanization}

9 Using a Geographic Information System, we calculated the area of inventory sites and their distance from the center of Paris, which is negatively correlated with intensity of urbanization

11 (linear regression, proportion of built up land $=1.18-0.05 \mathrm{x}$ distance, $r^{2}=0.83, \mathrm{P}<0.0001$ ). The Land $\underline{\text { Use }}$ Pattern (LUP, IAURIF 2003) is composed of 83 different classes, which were grouped into nine major classes for the present study (Table 2). Using MapInfo software (MapInfo corporation 2004), we defined a buffer around each site and estimated the proportion of each class within this buffer. To select the most relevant scale at which urbanization influences site floristic interest, we varied the buffer radius between $100 \mathrm{~m}$ and $2 \mathrm{~km}$ by steps of $100 \mathrm{~m}$.

\section{Relationship between floristic diversity and anthropogenic variables}

To assess the impact of broad-sense environment and urbanization on floristic interest, we explored the relationships between the floristic interest of sites (IFI) and (1) habitat type, (2)

21 site age, defined as the number of years during which the site LUP class remained the same (3) distance from the center of Paris, (4) the (Arcsine square-root transformed) proportion of the nine LUP classes in a buffer around the site. Because the IFI (species richness notably) strongly depends on site area, the latter was added as a quantitative covariate in the model. 
1 Hierarchical partitioning (Walsh \& McNally 2004) and randomization (500 times) were

2 conducted on $r^{2}$ values to isolate variables with a significant independent effect on the IFI (the

3 signs of the correlations were given by simple linear regressions) and to correct for

4 multicollinearity (McNally 2002).

\section{Observed vs. potential floristic interest}

6 Using observed IFI values at 986 sites and inverse distance weighted (IDW) interpolation, we

7 interpolated the IFI values in the non-sampled areas as a weighted average of a defined 8 number of neighborhood sites within a $1.5 \mathrm{~km}$-radius. The weight assigned to each 9 neighborhood site decreased with increasing distance to the unsampled areas. This generated a map of “interpolated floristic interest”. Although interpolation might be problematic in

11 highly structured landscapes, we showed that interpolation successfully predicted IFI in a 12 subset of 186 sites used as ground-truthed samples $(\mathrm{R}=0.364, \mathrm{p}<0.001$, mean over five 13 replicates).

14 We also built a map of potential floristic interest by extracting LUP classes with a significant effect on observed IFI and weighting their proportion by the R squares obtained from hierarchical partitioning. The Site Potential Value (SPV) was thus defined as follows:

$$
S P V=\sum_{i}(-1)^{j} r_{i}^{2} \times \operatorname{Arcsin} \sqrt{\text { area }_{i}}
$$
where $\operatorname{area}_{i}$ is the proportion of area covered by LUP class $i$ in a 200 m radius buffer; $j=1$ (2) for LUP classes with a negative (respectively positive) effect on observed IFI values. SPV was calculated for all inventoried sites and interpolated to the whole district (using IDW as described above) to generate the map of "potential floristic interest”. To assess whether SPV truly carried information on the actual floristic interest, we confronted it with ground-truthed samples by calculating SPV from a subsample of our dataset $(n=800$ sites sampled without 
1 replacement) and comparing predicted SPV values to observed IFI values in the remaining

2 sites $(\mathrm{n}=186$ sites). This operation was repeated five times.

3 


\section{RESULTS}

2 Over 986 sites we observed a total of 626 plant species, including 522 indigenous species and

3104 (16.6\%) naturalized species. Within habitats, the observed number of species varied

4 between 19 (aquatic vegetation) and 365 (wastelands, Table 1).

\section{$5 \quad$ Habitat Floristic interest}

6 To estimate the floristic interest of each habitat, we scored each index and the IFI separately

7 (Fig.2). Generally, the ranking of habitats varied across the four indices of floristic diversity.

8 However, habitats of high floristic interest were mostly found in intermediate or semi-natural

9 environments, as expected, whereas anthropogenic habitats were usually species-poor and

10 contained more common and non-indigenous species. For example, the largest species

11 richness was observed in wet thickets (42.3 species on average), a semi-natural habitat. In

total, semi-natural and intermediate habitats hosted 477 and 523 species, respectively,

whereas 315 species only were found in anthropogenic habitats. Except for the aquatic

14 habitat, typicality was rather uniform across habitats, whereas the rarity index was much more

15 discriminating: semi-natural habitats generally had a higher mean rarity index than anthropogenic habitats (0.90 vs. 0.83 on average), with the exception of gravestones and cracks of walls.

When habitats were ranked with respect to IFI, which synthesises all four indices, aquatic habitats came first despite their low specific richness (2.6 species per site, Fig.2), because they host species of high interest for conservation (rare, typical, indigenous species).

21 Anthropogenic habitats such as base of walls or spaces between paving stones had a significantly lower interest. Among the thirteen habitats with highest IFI, four represented less than $3 \%$ of total inventoried area (namely aquatic vegetation, wet thickets, wastelands after

24 culture, and embankments) and are thus likely to be also rare at the district scale. 


\section{Impact of urbanization on site floristic interest}

2 When examining the relationship between site floristic interest and the proportions of each

3 urbanization class (Table 2) in a buffer around the site, the buffer radius of $200 \mathrm{~m}$ generated

4 the best fit (Appendix S1) and was thus retained for subsequent analyses. At the site level, the

5 Index of Floristic Interest (IFI) varied between 0.29 and 0.76 . Quite expectedly, variation

6 among sites was explained by differences in site area, distance from the center of Paris and

7 habitat type (Fig.3): site interest was high in large sites, located away from Paris and in more

8 natural habitats. All land use classes had a significant influence on the floristic interest of a

9 site. In particular, increasing proportions of collective dwellings around a site were correlated with a lower site floristic interest. In contrast, the presence of water (rivers, ponds...), and, to

11 a lesser extent, woods, open and rural areas, vacant urban areas and building sites had a positive impact on the site IFI, whereas transport, activities, individual dwellings and facilities 13 in the neighborhood seemed to have a negative influence (Fig.3).

\section{Observed and potential floristic interest}

As expected, the regions of highest observed or interpolated floristic interest were found near the Seine River (Fig.4.I, A) or in forests (Fig.4.I, B), whereas highly urbanized or industrial areas exhibited low IFI (Fig.4.I, C). The Site Potential Value, calculated from known contributions of LUP classes surrounding sites, proved to carry meaningful information regarding site floristic interest, as shown by a significant relationship between SPV calculated from a subsample of sites and observed IFI ( $\mathrm{R}=0.204, \mathrm{p}<0.0001$; mean over 5 replicates), although this relationship varied across habitats (not shown). Therefore, site potential value generally exhibited the same patterns as interpolated IFI but proved very useful to identify specific sites with a high, but unrealized, potential (Fig.4). For example, all of the Seine River 
1 banks and two parks with ponds generally exhibited a moderate observed IFI together with

2 some of the highest values of potential IFI (Fig.4.II, D). 


\section{DISCUSSION}

2 As in most conservation plans, preserving biodiversity in urban zones requires to describe the

3 existing patterns of species and habitat diversity, and identify areas of highest conservation

4 interest (“comprehensive biotope mapping”, Sukopp \& Weiler 1988). However, biodiversity

5 cannot be efficiently managed without a good knowledge of the mechanisms affecting species

6 distribution, which, in highly human-dominated urban habitats, can be very different from the

7 usual ecological mechanisms acting in "natural" ecosystems. In the present study, we

8 inventoried habitats and plant species in a highly urbanized French district to (1) describe

9 species distribution, (2) locate sites and habitats of high interest, by building a new index of

floristic interest (IFI) and (3) evaluate the influence of urbanization on the floristic interest of

11 sites. We discuss the implication of these findings for the conservation of plant diversity in

12 the Hauts-de-Seine.

13 Distribution of floristic diversity in the Hauts-de-Seine

14 In the Hauts-de-Seine district, we recorded 626 vascular plant species in 23 habitats. In face

15 of similar studies in European urban areas, the observed species richness of the Hauts-deSeine is comparatively low. For example, Pysek (1993) inferred the mean floristic richness of urbanized zones as a function of city area, using inventories from 55 cities of Central Europe. Applying this regression to the Hauts-de-Seine $\left(176 \mathrm{~km}^{2}\right)$, we expect 763 species over the whole district, i.e. about 20\% more than what was observed in the present study (626 species). This suggests that plant diversity in the Hauts-de-Seine is slightly lower than the average of other European cities considered in Pysek (1993), but the difference might be attributable to: (1) differences in sampling effort, which is known to strongly influence the observed species richness (Hayek \& Buzas 1997) and (2) differences in urbanization level (the Hauts-de-Seine 
1 is part of the highly urbanized heart of Paris area $\left(2720 \mathrm{~km}^{2}\right)$, whereas the zones studied in

2 Pysek (1993) comprised entire city areas including less highly developed outskirts).

3 On average, we found that the Hauts-de-Seine district hosted $16.6 \%$ of naturalized species.

4 This was rather high compared with the national rate (9.4\%, Vitousek et al. 1996) but

5 comparable to an equivalent study in Brussels, where $19.8 \%$ of the vascular flora consisted of 6 naturalized species (Godefroid 2001). Higher levels of naturalized species in urban areas are a 7 general pattern (Kowarik 1995; Pysek 1998; Godefroid 2001), which can be explained by the 8 presence of a complex network of roads, railways, rivers, and airports, contributing here to the 9 dispersal and settlement of species such as Conyza sumatrensis, Solidago canadensis and Erigeron annuus.

Throughout the inventories, we observed five protected (one nationally and four regionally) species, three of which (Cardamine impatiens, Cuscuta europaea, and Thelypteris palustris) grow in wet habitats. Their presence legally justifies the preservation of wet zones, one of the most threatened habitats of urban areas. In Brussels, Godefroid (2001) showed that species of very humid to swamp soils were progressively replaced by more mesophilic taxa. In NewYork, DeCandido et al. (2004) also found that humid habitats were most disturbed, and 9.9\% of hosted species were rare or imperiled. These findings suggest that conservation of rare species is relevant also in cities.

The Index of Floristic Interest

Characteristics of IFI

The Index of Floristic Interest incorporates four equally weighted variables (species richness, typicality, indigeneity and rarity). The choice is necessarily subjective, but we believe that we have accounted for the most classical criteria used in conservation studies, where they are often considered alone. Therefore, in contrast to most approaches, where site floristic interest is generally estimated via species richness alone, IFI provides information on both the number 
1 and "quality" of present species. The three "quality" variables were chosen for their relevance

2 to conservation issues (e.g. Godefroid \& Koedam 2003), but also because they can be simply

3 and objectively measured. Other indices exist to evaluate habitats or sites, but they usually

4 include subjective criteria, such as potential value, intrinsic appeal (Ratcliffe 1977), or

5 inhabitant attitudes (Maleyx 2001) to account for social value. The "coefficient of

6 conservatism” is a good index of site floristic quality, accounting for plants' tolerance to

7 disturbance and fidelity to specific habitat integrity (Swink \& Wilhelm 1994). However, it is

8 assigned by experts, familiar with plant habitats of a specific region, and thus cannot be

9 applied uniformly across regions. Other criteria, such as the recorded history of a site

10 (Ratcliffe 1977) provide potentially useful information but may not be available for some

11 sites and regions. In contrast, provided clear definitions are agreed upon (notably for

12 indigeneity), IFI should be a simple, objective and repeatable index, devoid of subjective

13 estimations. In addition, and most importantly, it can be readily used at a minimal cost in

14 numerous cities where floristic presence/absence data already are available (though poorly

15 published) in botanical gardens or conservatories, thanks to the work of amateur or

16 professional botanists. As such, this index can prove a useful tool to evaluate the biodiversity

17 of sites and habitats and identify locations of highest priority for conservation (see below).

18 Nonetheless, besides the simple fact that information is always lost in the process of summarizing different variables, IFI suffers one noticeable shortcoming inherent to its construction. Although the different variables incorporated in IFI are generally little

21 correlated to one another, rarity and typicality exhibit non negligible levels of correlation

22 (spearman $\rho=0.39, \mathrm{P}<0.0001$ ). This is due to the fact that, at a small spatial scale, rare

23 species (e.g. observed in a single site) are also categorized as 'typical'. This suggests that IFI

24 is to be used for comparison between sites of regions at least as large as a French district (a

25 few hundreds of $\mathrm{km}^{2}$ ), as typicality and rarity are meaningless at too small spatial scales. 


\section{Evaluation of habitat interest}

2 By synthesizing information on the quantity and quality of species, IFI proved a useful tool to

3 identify such patterns and define conservation priorities, two tasks that could not have been

4 correctly achieved by considering single variables and notably species richness alone. For

5 example, the aquatic vegetation was the poorest habitat in terms of species number, but

6 exhibited the highest rates of rare typical and indigenous species. Wet zones are thus a habitat

7 of high interest for conservation, which is highly threatened by urbanization and is now 8 poorly represented in the district (Table 1).

9 Here we focused on a single group, but floristic diversity is only one part of the evaluation process in nature conservation. Analysis of other groups could provide a better image of

11 ecosystems and their conservation status. Moreover, the index of floristic interest was created

12 from the point of view of the scientific conservationist only, it would be very helpful to 13 integrate sociological (Hope et al. 2003; Kinzig et al. 2005) and economic dimensions to 14 evaluate the effectiveness of management choices.

\section{Site interest and the mechanisms controlling floristic diversity in urban areas}

The Index of Floristic Interest was calculated in each of 986 sites, but also interpolated to the whole district (Fig.4.I). Although interpolation should be interpreted with caution in highly fragmented urban landscapes, we believe it is relevant here, because IFI was spatially autocorrelated across sites within $3 \mathrm{~km}$ (results not shown) and because the average minimum distances among site centers was small $(150 \mathrm{~m})$, so that IFI at a given site was correctly predicted by interpolation from neighboring sites.

To evaluate the impact of urbanization on biodiversity on a finer scale, we characterized the relationships between site floristic interest and urban environment, defined as the (transformed) proportion of nine classes of the Land Use Pattern in a 200m-disc around the sites (Table 2). The results of the analysis showed that the variability explained by each LUP 
1 class was low, because numerous other factors act on floristic diversity. Nevertheless, after

2 eliminating the effects of habitat type, site area and distance to the center of Paris, all retained

3 LUP classes had a significant impact on the site floristic interest. The presence of non-built

4 zones (rivers and ponds notably, and, to a lesser extent, forests, open urban and rural areas,

5 and vacant urban sites) had a positive impact on flora. In contrast, all classes of built zones,

6 and especially collective dwellings, had a significant negative influence on floristic interest,

$7 \quad$ with major consequences for management plans.

8 Thanks to this quantification of the effects of urban structures on floristic diversity, we were 9 able to infer a potential floristic interest (Fig.4.II), accounting for the existing urban structures around a site. The significant correlation observed between the predicted SPV and the 11 observed IFI suggests that SPV yields satisfying predictions regarding site interest, and that 12 the comparison of the map of potential interest with the map of observed IFI (Fig.4.I) provides a useful tool for the definition of conservation strategies, and the identification of habitats that should be priorities for management and conservation. For example, the Seine River banks are zones of high potential floristic interest, but of generally low realized interest, due to inadequate management: when banks are concreted, the benefits of the aquatic habitat are lost. Biotechnical methods, such as live stakes, brushlayering, live cribwall, joint planting and tree revetment may be applied to stabilize river banks without destroying the vegetation (Li \& Eddleman 2002). Large parks containing ponds are another example of zones with lower than expected floristic interest, (Fig.4.II, D): in these parks, intensive ornamental management may destroy indigenous biodiversity, which negatively impacts the biodiversity of surrounding green structures. 


\section{APPLICATIONS}

2 Resources for conservation actions are always limited, especially for conservation of urban

3 habitats and species, so that priorities have to be defined. This requires tools to quickly and

4 efficiently evaluate the conservation interest of species, sites and habitats. Here, we proposed

5 a new Index of Floristic Interest, combining objective quantitative and qualitative information

6 on floristic diversity; this index can be used by managers of green areas, in combination with

7 knowledge of the factors influencing floristic interest, to make decisions regarding the 8 preservation of biodiversity in urban areas.

9 In the Hauts-de-Seine, we demonstrated that "semi-natural" habitats, such as forests and wet zones, exhibited a high floristic interest and were the main reservoir of native biodiversity of

11 the district. As such habitats are generally restricted at the district scale, and since species 12 richness is positively correlated with area, they should be entirely preserved. Forests, for 13 example, host a large number of rare species. Intermediate environments exhibit the highest 14 plant richness, which is essentially concentrated in wastelands (365 species) and urban lawns (303 species). These habitats, which are well represented in the district, should be managed in a sustainable way to prevent (1) invasion by exotic species and (2) species homogenization 17 among sites, reducing the percentage of typical species. We finally highlighted that some sites 18 were characterized by large differences between the realized and potential IFI. Special attention should be given to such sites, to either (1) identify the effective management choices that explain the larger than expected site interest when IFI >> SPV or (2) to improve

21 management in sites where SPV >>IFI. 


\section{ACKNOWLEDGEMENTS}

2 We thank Sébastien Filoche for his help in floristic determination. Funding for this research 3 was provided by the Conseil Général des Hauts-de-Seine. 


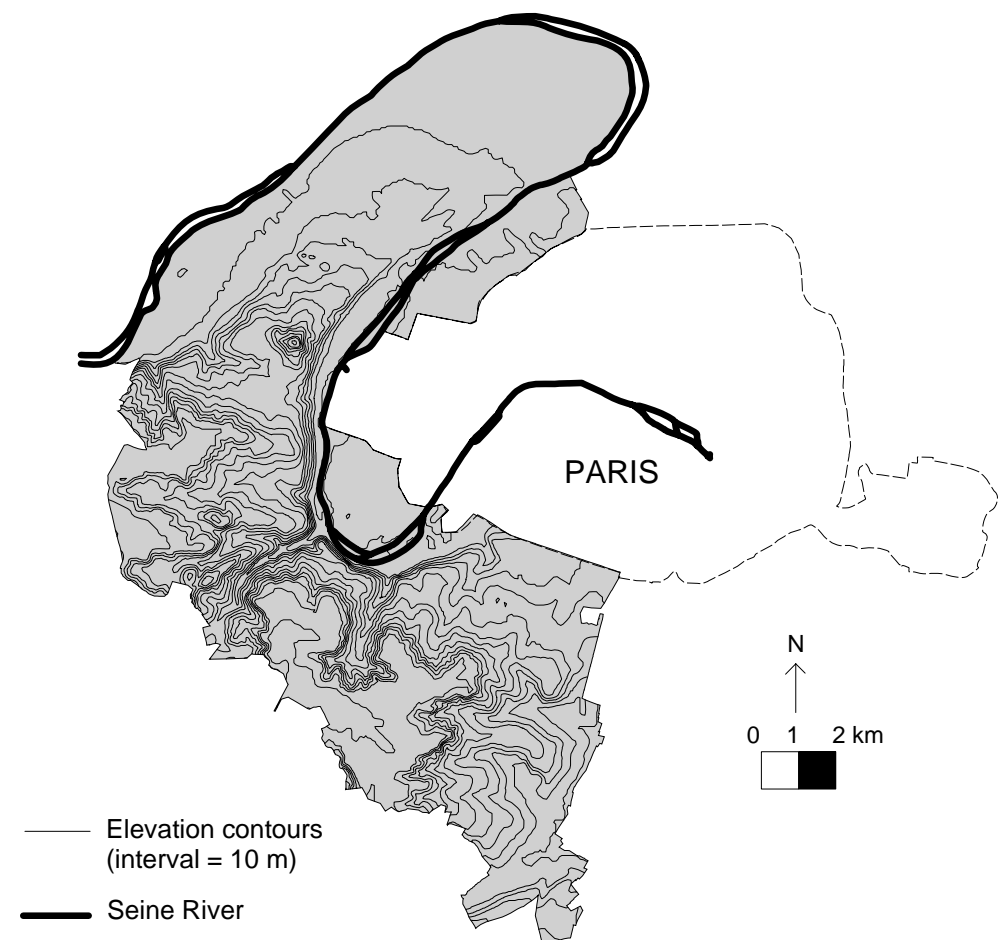

2

Fig.1. Location of the study area (in grey): the French district of Hauts-de-Seine. 

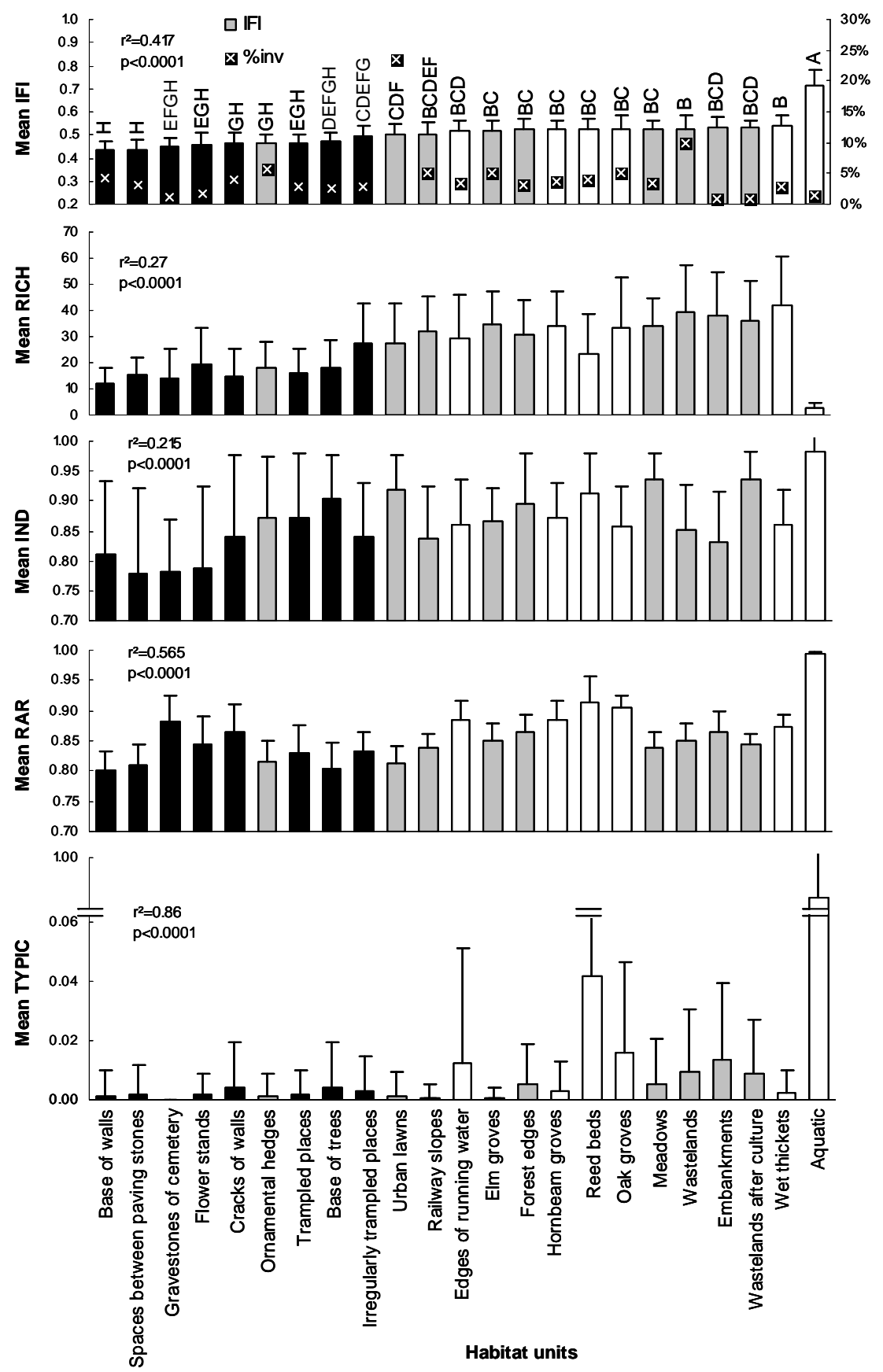

2 Fig.2. Mean values of floristic interest variables across habitats (Rich: species richness,

3 Typic: proportion of typical species, Ind: proportion of indigenous species, Rar: mean rarity

4 index and IFI: Index of Floristic Interest) and percentage of sites inventoried for each habitat

5 (\%inv, top figure). Significant differences $(\mathrm{p}=0.05)$ between IFI values are shown by different

6 letters (Tukey's test). Semi-natural habitats are in white, intermediate habitats in grey, and

7 anthropogenic habitats in black. 


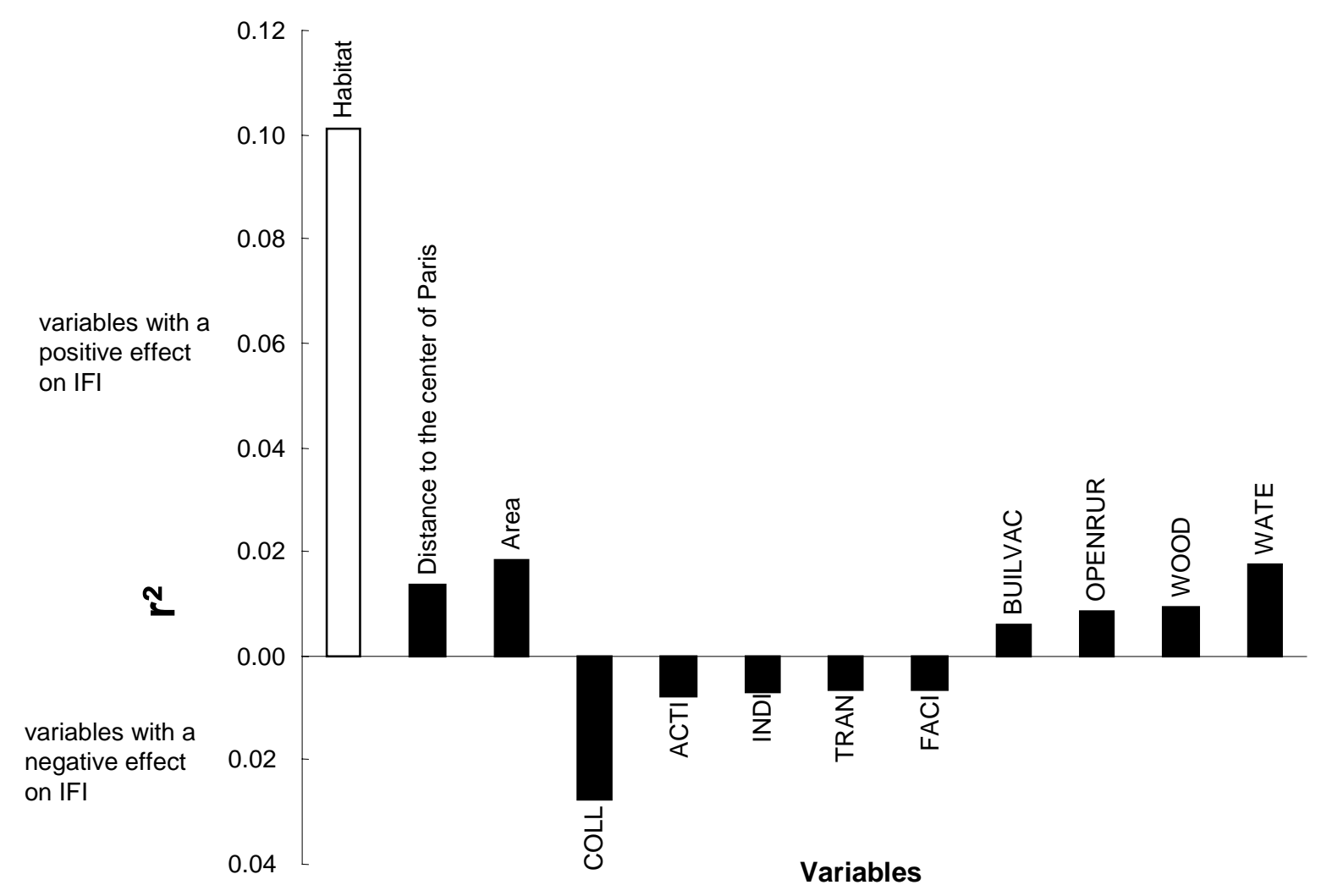

2 Fig.3. Distribution of $r^{2}$ of independent effects on IFI, calculated from hierarchical 3 partitioning (500 randomizations). All contributions are significant at the upper 95\% 4 confidence limit. All variables are quantitative (in black) except habitat (in white). See table 2 5 for definition of LUP classes. 


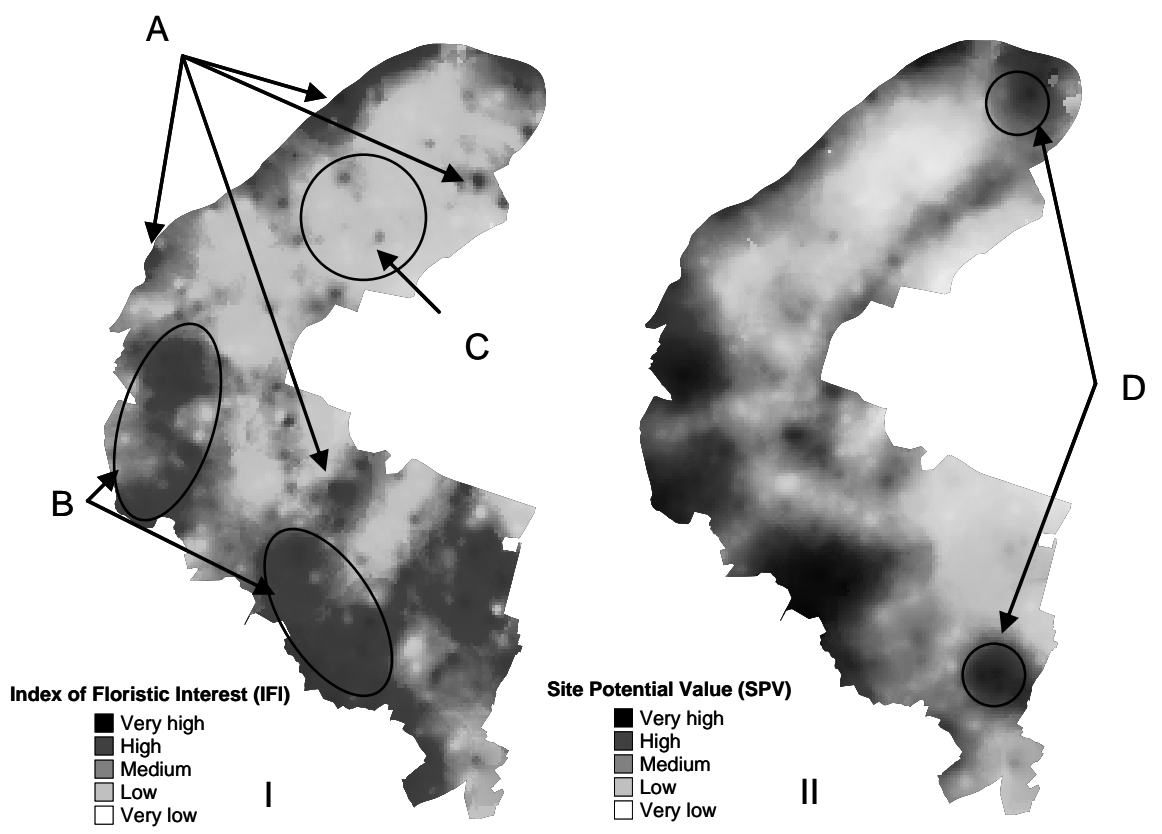

3

4 Fig.4. Distribution of interpolated and potential floristic interest in the Hauts-de-Seine. (I):

5 Distribution of IFI inferred from the IDW interpolation (zones of higher interest are darker).

6 (A), (B): examples of high interest zones: the Seine river banks (A) and forests (B); (C):

7 example of a low interest zone: an industrial zone. (II): Distribution of potential floristic

8 interest inferred from IDW interpolation. (D): Example of zones of high potential interest:

9 two parks containing ponds. 
1 Table 1. The 23 habitats of the Hauts-de-Seine, as defined from vegetation units of the

2 Parisian region (Bournérias et al., 2001), together with the total number of species and the

3 total area inventoried in each habitat.

\begin{tabular}{|c|c|c|c|c|c|c|c|c|}
\hline \multicolumn{3}{|c|}{ Semi-natural environment } & \multicolumn{3}{|c|}{ Intermediate environment } & \multicolumn{3}{|c|}{ Anthropogenic environment } \\
\hline Habitat & $\begin{array}{l}\text { No. of } \\
\text { species }\end{array}$ & $\begin{array}{l}\text { Area } \\
\text { in ha }\end{array}$ & Habitat & $\begin{array}{l}\text { No. of } \\
\text { species }\end{array}$ & $\begin{array}{l}\text { Area } \\
\text { in ha }\end{array}$ & Habitat & $\begin{array}{l}\text { No. of } \\
\text { species }\end{array}$ & $\begin{array}{l}\text { Area } \\
\text { in ha }\end{array}$ \\
\hline Aquatic & 19 & 0.002 & Elm groves & 279 & 20.13 & Cracks of walls & 179 & 5.97 \\
\hline $\begin{array}{l}\text { Edges of } \\
\text { running water }\end{array}$ & 232 & 15.25 & Embankments & 161 & 0.83 & Base of trees & 138 & 3.50 \\
\hline $\begin{array}{l}\text { Hornbeam } \\
\text { groves }\end{array}$ & 220 & 45.40 & Forest edges & 226 & 9.84 & Base of walls & 119 & 9.78 \\
\hline Oak groves & 263 & 85.14 & Meadows & 231 & 16.91 & $\begin{array}{l}\text { Gravestones of } \\
\text { cemetery }\end{array}$ & 82 & 20.18 \\
\hline Reed beds & 261 & 10.14 & $\begin{array}{l}\text { Ornamental } \\
\text { hedges }\end{array}$ & 197 & 7.79 & $\begin{array}{l}\text { Irregularly } \\
\text { trampled places }\end{array}$ & 208 & 7.25 \\
\hline \multirow[t]{4}{*}{ Wet thickets } & 285 & 8.57 & Railway slopes & 249 & 14.30 & $\begin{array}{l}\text { Spaces between } \\
\text { paving stones }\end{array}$ & 140 & 4.10 \\
\hline & & & Urban lawns & 303 & 98.35 & Trampled places & 158 & 2.82 \\
\hline & & & Wastelands & 365 & 21.90 & Flower stands & 122 & 6.52 \\
\hline & & & $\begin{array}{l}\text { Wastelands after } \\
\text { culture }\end{array}$ & 127 & 1.64 & & & \\
\hline
\end{tabular}


1 Table 2. Description of the nine LUP classes (IAURIF, 2003)

\begin{tabular}{|c|c|c|}
\hline Abbreviation & Land Use Patterns & Definition \\
\hline ACTI & Activities & Warehouses, Offices, Companies \\
\hline BUILVAC & $\begin{array}{l}\text { Building sites and Vacant } \\
\text { urban }\end{array}$ & \\
\hline COLL & Collective dwellings & Tall buildings covering large areas \\
\hline FACI & Facilities & $\begin{array}{l}\text { Education, Health, Administration, } \\
\text { Cemeteries, Electricity, Gas, Petroleum }\end{array}$ \\
\hline INDI & Individual dwellings & Houses, including small privative gardens \\
\hline OPENRUR & $\begin{array}{l}\text { Open urban areas } \\
\text { Rural areas }\end{array}$ & $\begin{array}{l}\text { Parks, Gardens, Sports, Camping, Golf, } \\
\text { Hippodrome } \\
\text { Truck farming, horticulture, orchards, } \\
\text { breeding grounds, pits }\end{array}$ \\
\hline TRAN & Transportation & Railways, Highways, Streets, Parking lots \\
\hline WATE & Water & \\
\hline WOOD & Woods and forests & \\
\hline
\end{tabular}

2 


\section{LITTERATURE CITED}

Angold, P.G., Sadler, J.P., Hill, M.O., Pullin, A., Rushton, S., Austin, K., Small, E., Wood, B., Wadsworth, R., Sanderson, R., Thompson, K. 2006. Biodiversity in urban habitat patches. Science of The Total Environment 360: 196-204.

Bournérias, M., Arnal, G., Bock, C. 2001. Guide des groupements végétaux de la région parisienne, 4th ed. Belin eds, Paris.

CBNBP. 2008. Conservatoire Botanique National du Bassin Parisien. http://cbnbp.mnhn.fr/cbnbp

Dana, ED, Vivas, S., Mota, J.F. 2002. Urban vegetation of Almeria City--a contribution to urban in Spain. Landscape and Urban Planning 59:203-216.

DeCandido, R. 2004. Recent changes in plant species diversity in urban Pelham Bay Park, 1947-1998. Biological Conservation 120:129-136.

DeCandido, R., Muir, A.A., Gargiullo, M.B. 2004. A first approximation of the historical and extant vascular flora of New York City: Implications for native plant species conservation. Journal of the Torrey Botanical Society 131:243-251.

Dewilde, J.F., Lafréchoux, C. 2001. Le Cadastre vert des Hauts-de-Seine. Nanterre: Direction des Espaces verts, Conseil Général des Hauts-de-Seine.

Godefroid, S. 2001. Temporal analysis of the Brussels flora as indicator for changing environmental quality. Landscape and Urban Planning 52:203-224.

Godefroid, S., Koedam, N. 2003. Identifying indicator plant species of habitat quality and invasibility as a guide for peri-urban forest management. Biodiversity and Conservation 12:1699-1713.

Godefroid, S., Koedam, N. 2007. Urban plant species patterns are highly driven by density and function of built-up areas. Landscape Ecology 22: 1227-39 
1 Goodfellow, S., Peterken, G.F. 1981. A method for survey and assessment of woodlands for

2 nature conservation using maps and species lists: The example of Norfolk woodlands.

$3 \quad$ Biological Conservation 21:177-195.

4 Grimm, N.B., Morgan Grove, J., Pockett, S.T.A., Redman, C.L. 2000. Integrated Approaches to Long-Term Studies of Urban Ecological Systems. BioScience 50: 571-584.

Hayek, L-A.C., Buzas, M.A. 1997. Species Diversity: The Number of Species. In: Surveying

Hermy, M., Cornelis, J. 2000. Towards a monitoring method and a number of multifaceted and hierarchical biodiversity indicators for urban and suburban parks. Landscape and Urban Planning 49:149-162.

Hope, D., Gries, C., Zhu, W., Fagan, W. F., Redman, C. L., Grimm, N. B., Nelson, A. L., Martin, C., Kinzig, A. 2003. Socioeconomics drive urban plant diversity. PNAS, 100(15): 8788-8792.

IAURIF. 2003. Institute for Planning and Development of the Paris Ile-de-France Region. http://www.iaurif.org

INSEE. 1999. National Institute for Statistics and Economic Studies. http://www.insee.fr

Kendle, T., Forbes, S. 1997. Urban Nature Conservation: Landscape management in the urban countryside. Spon press, London.

Kent, M., Stevens, R.A., Zhang, L. 1999. Urban plant ecology patterns and processes: a case

Kinzig, A.P., Warren, P., Martin, C., Hope, D., Katti, M. 2005. The Effects of Human study of the flora of the City of Plymouth, Devon, U. K. Journal of Biogeography 26:1281-1298. Socioeconomic Status and Cultural Characteristics on Urban Patterns of Biodiversity. Ecology and Society 10: 23 
1 Kowarik, I. 1995. Time lags in biological invasions with regard to the success and failure of

2 alien species. In: Pysek, P., Prach, K., Rejmànek, M., Wade, M. (eds.) Plant invasions:

3 General aspects and special problems, pp. 15-38. SPB Academic publishing, Amsterdam.

4 Kühn, I., Klotz, S. 2006. Urbanization and homogenization - Comparing the floras of urban

$5 \quad$ and rural areas in Germany. Biological Conservation 127:292-300.

6 Li, M-H., Eddleman, K.E. 2002. Biotechnical engineering as an alternative to traditional

$7 \quad$ engineering methods: A biotechnical streambank stabilization design approach.

$8 \quad$ Landscape and Urban Planning 60:225-242.

9 Lofvenhaft, K., Bjorn, C., Ihse, M. 2002. Biotope patterns in urban areas: a conceptual model integrating biodiversity issues in spatial planning. Landscape and Urban Planning 58:223-240.

Maleyx, J-N. 2001. Schéma départemental des espaces naturels sensibles des Hauts-de-Seine. Nanterre: Direction des espaces verts, Conseil Général des Hauts-de-Seine.

MapInfo, MapInfo corporation. 2004. MapInfo professional version 7.8

Maurer, U., Peschel, T., Schmitz, S. 2000. The flora of selected urban land-use types in Berlin and Potsdam with regard to nature conservation in cities. Landscape and Urban Planning $46: 209-215$

McKinney, M.L. 2006. Urbanization as a major cause of biotic homogenization. Biological Conservation 127: 247-60

McNally, R. 2002. Multiple regression and inference in ecology and conservation biology: further comments on identifying important predictor variables. Biodiversity and Conservation 11:1397-1401.

Muratet, A., Machon, N., Jiguet, F., Moret, J., Porcher, E. 2007. The Role of Urban Structures in the Distribution of Wasteland Flora in the Greater Paris Area, France. Ecosystems 10(4): 661-671. 
1 Mushet, D., Euliss, N.J., Shaffer, T. 2002. Floristic quality assessment of one natural and

2 three restored wetland complexes in North Dakota, USA. Wetlands 22: 126-138.

3 Pyšek, P. 1993. Factors affecting the diversity of flora and vegetation in central European

$4 \quad$ settlements. Vegetatio 106: 89-100.

5 Pyšek, P. 1998. Alien and native species in Central European urban floras: A quantitative $6 \quad$ comparison. Journal of Biogeography 25: 155-63

7 R Development, Core Team. 2004. R: A language and environment for statistical computing.

Ratcliffe, D.A. 1977. A Nature Conservation Review. Syndics of the Cambridge University Press, Cambridge.

Richardson, D.M., Pyšek, P., Rejmánek, M., Barbour, M.G., Panetta, F.D., West, C.J. 2000. Naturalization and invasion of alien plants: concepts and definitions. Diversity \&

Ricotta, C., Celesti Grapow, L., Avena, G., Blasi, C. 2001. Topological analysis of the spatial Distributions 6:93-107. distribution of plant species richness across the city of Rome (Italy) with the echelon approach. Landscape and Urban Planning 57:69-76.

Roy, D.B., Hill, M.O., Rothery, P. 1999. Effects of urban land cover on the local species pool in Britain. Ecography 22: 507-17.

Shochat, E., Warren, P.S., Faeth, S.H., McIntyre, N.E., Hope, D. 2006. From patterns to emerging processes in mechanistic urban ecology. Trends in Ecology \& Evolution 21:186191.

Spellerberg, I.F. 1992. Evaluation and Assessment for Conservation. Chapman \& Hall, London.

Sukopp, H., Weiler, S. 1988. Biotope mapping and nature conservation strategies in urban areas of the Federal Republic of Germany. Landscape and Urban Planning 15: 39-58. 
1 Swink, F.A., Whilhelm, G.S. 1994. Plants of the Chicago Region. Indiana Academy of

2 Science, Indianapolis.

3 Thompson, K., Hodgson, J. G., Smith, R. M., Warren, P. H., \& Gaston, K. J. 2004. Urban

4 domestic gardens (III): Composition and diversity of lawn floras. Journal of Vegetation

$5 \quad$ Science 15(3): 373-378.

6 Tzoulas, K., Korpela, K., Venn, S., Yli-Pelkonen, V., Kazmierczak, A., Niemela, J., \& James,

$7 \quad$ P. 2007. Promoting ecosystem and human health in urban areas using Green

8 Infrastructure: A literature review. Landscape and Urban Planning 81(3): 167-178.

9 Vitousek, P.M., D'Antonio, L.C.M., Loope, L., Westbrooks, R. 1996. Biological invasions as global change. American Scientist 84:468-478.

11 Walsh, C., McNally, R. 2004. hier.part: Hierarchical Partitioning. R package.

12 Westhoff, V., Werner, P. 1983. Man's attitude towards vegetation. In: Wall, M.J.A. \& Holzner 13 W. (eds.) Man's impact on vegetation, pp. 7-24. Dr W.Junk Publishers, The Hague.

14 Wittig, R., Schreiber, K-F. 1983. A quick method for assessing the importance of open spaces 15 in towns for urban nature conservation. Biological Conservation 26:57-64.

16 Zerbe, S., Maurer, U., Schmitz, S., Sukopp, H. 2003. Biodiversity in Berlin and its potential 17 for nature conservation. Landscape and Urban Planning 62: 139-148. 


\section{SUPPLEMENTARY MATERIAL}

2 Appendix S1. Total independent variance $\left(\mathrm{r}^{2}\right)$ explained by a model including (1) the area of

3 each LUP classes in the buffer, (2) the site area, (3) the site distance to the center of Paris and

4 (4) habitat type, for each variable of floristic interest (IFI: Index of Floristic Interest, Rich:

5 species richness, Rar: mean rarity index, Typic: proportion of typical species and Ind:

6 proportion of indigenous species) using hierarchical partitioning

\begin{tabular}{lccccc}
\hline Circle radius & IFI & Rich & Rar & Typic & Ind \\
\hline $100 \mathrm{~m}$ & 0.222 & 0.148 & 0.306 & 0.310 & 0.132 \\
$200 \mathrm{~m}$ & $\mathbf{0 . 2 3 0}$ & $\mathbf{0 . 1 5 2}$ & $\mathbf{0 . 3 3 0}$ & $\mathbf{0 . 3 1 7}$ & $\mathbf{0 . 1 4 7}$ \\
$300 \mathrm{~m}$ & 0.229 & 0.151 & 0.322 & 0.314 & 0.143 \\
$400 \mathrm{~m}$ & 0.225 & 0.149 & 0.315 & 0.312 & 0.136 \\
$500 \mathrm{~m}$ & 0.222 & 0.148 & 0.306 & 0.310 & 0.132 \\
$1 \mathrm{~km}$ & 0.207 & 0.144 & 0.262 & 0.304 & 0.118 \\
$2 \mathrm{~km}$ & 0.197 & 0.153 & 0.240 & 0.300 & 0.104 \\
\hline
\end{tabular}

7

8 